\title{
Tinjauan Metode Penangkapan Karbon untuk PLTU Batubara
}

\section{Satyo Jati Prakoso, Jaka Windarta}

Magister Energi, Sekolah Pascasarjana, Universitas Diponegoro;

Email : satyojati@students.undip.ac.id (S.J.P), jakawindarta@lecturer.undip.ac.id (J.W);

\begin{abstract}
Abstrak : Sektor energi adalah kontributor utama dalam emisi karbon di Indonesia. Dengan meningkatnya kebutuhan energi, maka emisi karbon dari sektor ini juga meningkat tiap tahunnya. Sampai tahun 2023 akan ada lebih dari 15 GW PLTU Batubara baru yang mulai beroperasi. Lambatnya perkembangan energi bersih yang ekonomis membuat Indonesia harus mulai mempertimbangkan teknologi lain untuk menurunkan emisi karbon. Salah satu yang layak dipertimbangkan adalah teknologi penangkapan karbon. Penelitian ini mengulas metode - metode penangkapan karbon yang ada juga kelebihan dan kekurangannya. Metode penangkapan paska pembakaran dianggap layak untuk dipertimbangkan karena lebih mudah diterapkan pada pembangkit yang sudah ada. Penelitian lebih jauh diperlukan untuk menurunkan kebutuhan energi dan biaya dari teknologi penangkapan karbon.
\end{abstract}

Kata Kunci : Emisi Karbon, Batubara, Penangkapan Karbon

\section{Pendahuluan}

Data BPS menunjukan Indonesia telah berhasil menurunkan emisi karbon dari 2,3 GT pada tahun 2015 menjadi 1,1 GT pada tahun 2017. Kontributor utama penurunan dramatis ini adalah keberhasilan Indonesia dalam mengendalikan kebakaran hutan yang merupakan penyumbang emisi karbin terbesar di tahun 2015 dan 2016.

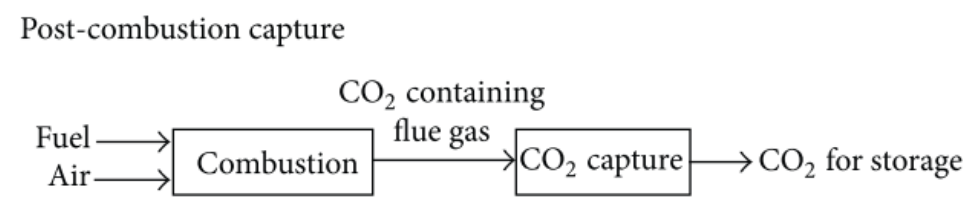

Oxy fuel combustion

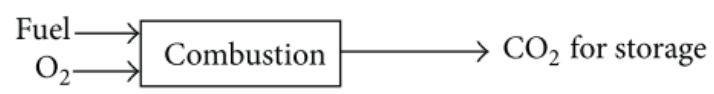

Pre-combustion capture

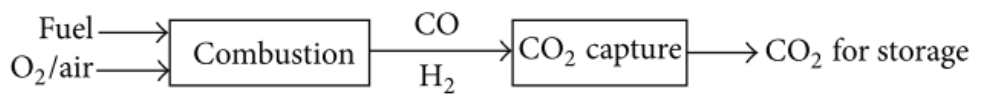

Gambar 1. Tiga Pendekatan dalam Penangkapan $\mathrm{CO}_{2}$ (Thiruvenkatachari et al., 2009) 
Vol. 2, No. 1, pp $27-35$

doi: $10.14710 /$ jebt.2021.10046

Keberhasilan ini patut diapresiasi. Selanjutnya Indonesia perlu fokus pada kontributor utama lainnya, yaitu sektor energi. Secara tradisional, sektor energi adalah kontributor utama pada emisi karbon Indonesia. Hampir 50\% dari total emisi karbon 2017 bersal dari sektor ini (BPS,2018). Dengan meningkatnya kebutuhan energi, maka emisi karbon dari sektor energi juga semakin meningkat tiap tahunnya. Batubara sebagai sumber energi primer paling murah dan paling kotor tetap menjadi primadona di Indonesia. Dalam perencanaan PLN, kontribusi energi primer batubara akan mencapai 66.60\%. Naik dari realisasi $57.22 \%$ di tahun 2017. Hal ini disebabkan karena total 15 GW PLTU batubara baru akan bergabung ke Grid sampai dengan 2023 (RUPTL PT. PLN, 2019).

Jika Indonesia tidak mengambil langkah strategis maka kenaikan emisi karbon dalam beberapa tahun kedepan adalah sebuah keniscayaan. Indonesia selayaknya mulai mempertimbangkan pilihanpilihan yang ada untuk mengurangi emisi karbon. Salah satu pilihannya adalah dengan menerapkan teknologi penangkapan dan penyimpanan karbon (carbon capture and storage, CCS). Tulisan ini akan membahas teknologi CCS yang ada dan mengulas hasil kajian-kajian CCS sehingga data yang disajikan dapat digunakan oleh pemangku kebijakan.

\section{Carbon Capture Technologies}

Pada dasarnya, ada tiga rute utama sistem penangkapan $\mathrm{CO}_{2}$ : pasca-pembakaran, prapembakaran, dan pembakaran bahan bakar oxy. Penangkapan pra-pembakaran - adalah gasifikasi batubara untuk membentuk gas sintesis, yang dapat dialihkan untuk menghasilkan campuran gas kaya $\mathrm{H}_{2}$ dan $\mathrm{CO}_{2}$, di mana $\mathrm{CO}_{2}$ dapat ditangkap dan dipisahkan secara efisien, diangkut, dan akhirnya disimpan. Penangkapan pra-pembakaran melibatkan mereaksikan batubara dengan oksigen atau udara atau uap untuk menghasilkan gas sintesis yang terdiri dari karbon monoksida dan hidrogen. Karbon monoksida direaksikan dengan uap dalam reaktor katalitik, yang disebut konverter geser, menghasilkan $\mathrm{CO}_{2}$ dan hidrogen. $\mathrm{CO}_{2}$ kemudian dipisahkan, biasanya melalui proses penyerapan fisik atau kimia, menghasilkan bahan bakar kaya hidrogen yang dapat digunakan dalam banyak aplikasi, seperti boiler, tungku, turbin gas, mesin, dan sel bahan bakar.

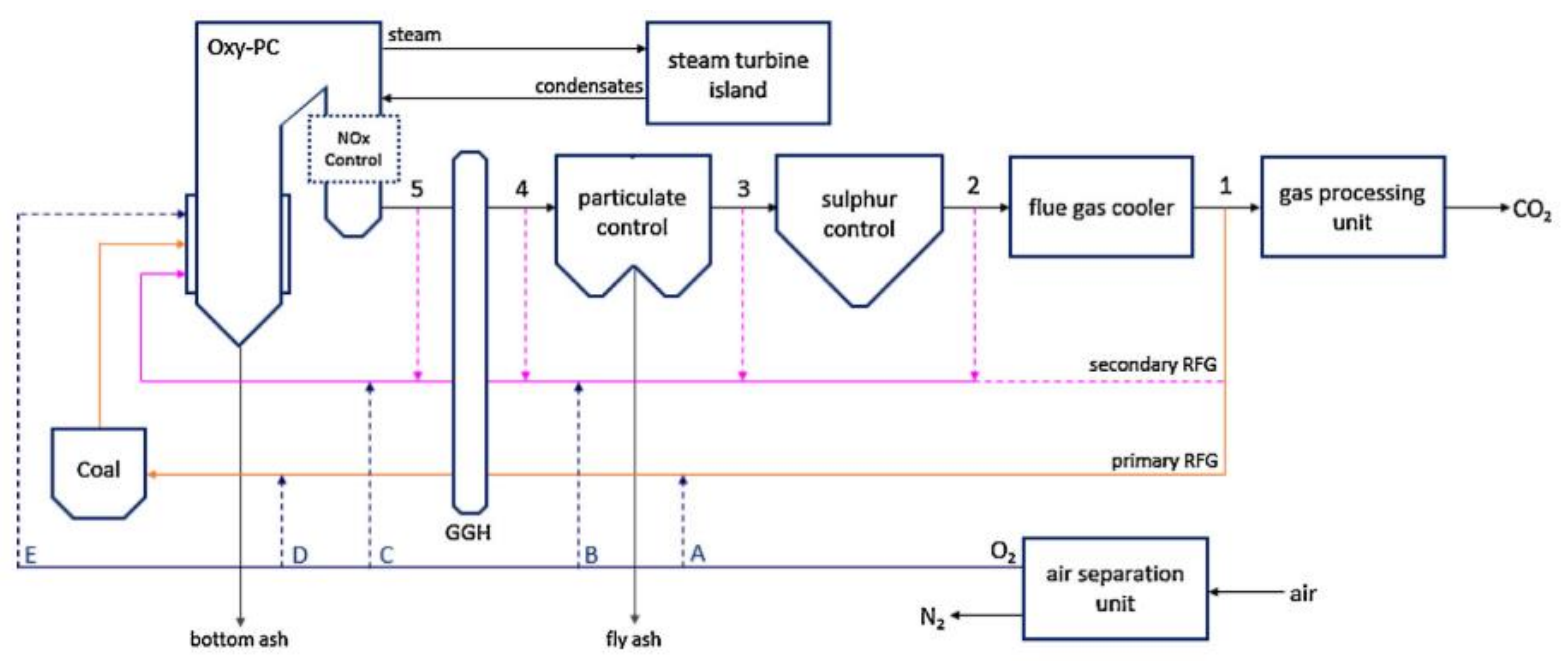

Gambar 2. Diagram Aliran Skematik Sederhana dari Pembangkit Listrik Tenaga Batu Bara Oxy-PC dengan Penangkapan $\mathrm{CO}_{2}$ (Stanger et al., 2015). 


\subsection{Pembakaran Oxy-Fuel}

Prinsip pembakaran oksifuel adalah pembakaran batu bara dalam oksigen daripada udara, menghasilkan aliran flue gas yang sebagian besar terdiri dari $\mathrm{CO}_{2}$ dan air, sehingga $\mathrm{CO}_{2}$ dapat dimurnikan dengan relatif mudah. Untuk pembangkit listrik konvensional menggunakan pembakaran batubara, konsentrasi $\mathrm{CO}_{2}$ dalam flue gas relatif rendah $(12 \%-16 \%$ dry base). Dalam kasus boiler batubara oxy-fuel, udara diganti dengan oksigen murni dan menghasilkan flue gas yang mengandung konsentrasi $\mathrm{CO}_{2}$ yang tinggi (65\% - 85\% dry base) (Stanger et al., 2015). Ruang bakar yang tidak mengakomodasi nitrogen membuat ukuran ruang bakar menjadi lebih kecil. Namun biaya dan energi yang dibutuhkan memproduksi oksigen murni sangat mahal (Edge et al., 2011) dan belum ada penerapan teknologi ini untuk pembangkit skala besar (Sifat \& Haseli, 2019). Desain boiler yang baru juga diperlukan untuk mengurangi terbentuknya Nox karena temperature pembakaran yang tinggi (Yuan et al., 2017).

\subsection{Penangkapan Pra-Pembakaran}

Penangkapan pra-pembakaran melibatkan reaksi bahan bakar dengan oksigen atau udara atau uap untuk menghasilkan gas yang terdiri dari karbon monoksida dan hidrogen, yang dikenal sebagai gas sintesis (syngas) atau gas bahan bakar. Karbon monoksida yang diproduksi bereaksi dengan uap dalam reaktor katalitik, yang disebut konverter shift, untuk menghasilkan $\mathrm{CO}_{2}$ dan hidrogen. $\mathrm{CO}_{2}$ kemudian dipisahkan, biasanya dengan distilasi kriogenik atau proses penyerapan kimia, menghasilkan bahan bakar kaya hidrogen yang dapat digunakan dalam banyak aplikasi, seperti boiler, turbin gas, mesin dan sel bahan bakar.

Penangkapan karbon pra-pembakaran sebagian besar digunakan dalam industri proses. Ada juga pabrik penangkapan carbon skala penuh di beberapa industri yang menggunakan metode ini (Jansen et al., 2015). Konsentrasi $\mathrm{CO}_{2}$ jauh yang tinggi dalam flue gas dari proses ini dibandingkan campuran flue gas konvensional. Karena tekanan yang lebih tinggi dan volume gas yang lebih rendah, lebih sedikit energi diperlukan dalam proses ini dibandingkan dengan penangkapan paska pembakaran. Tetapi tetap saja, kebutuhan energi tinggi. Prekombinasi terutama digunakan dalam teknologi siklus gabungan gasifikasi terintegrasi. Teknologi ini memerlukan sistem pendukung yang besar untuk kelancaran operasi. Oleh karena itu, biaya modal sistem ini terlalu tinggi dibandingkan dengan sistem lain (Sifat \& Haseli, 2019).

\subsection{Penangkapan Pasca-Pembakaran}

Penangkapan pasca-pembakaran menggambarkan teknik penangkapan karbon dengan cara memisahkan $\mathrm{CO}_{2}$ dari flue gas pembangkit listrik berbahan bakar fosil konvensional. Salah satu tantangan terbesar dalam besarnya energi yang diperlukan untuk memisahkan $\mathrm{CO}_{2}$ dari flue gas (Lockwood, 2017). Tantangan lainnya adalah aliran flue gas biasanya 5 - 10 kali lebih cepat dari pada aliran gas yang diolah pada gas alam dan industri kimia(Merkel et al., 2010).

Terlepas dari kesulitan ini, penangkapan karbon pasca-pembakaran memiliki potensi jangka pendek terbesar untuk mengurangi emisi GRK, karena dapat dipasang kembali ke unit yang ada (Figueroa et al., 2008). Beberapa kajian telah dilakukan untuk penangkapan $\mathrm{CO}_{2}$ pasca-pembakaran termasuk absorpsi, adsorpsi, membran, dan pemisahan kriogenik. 


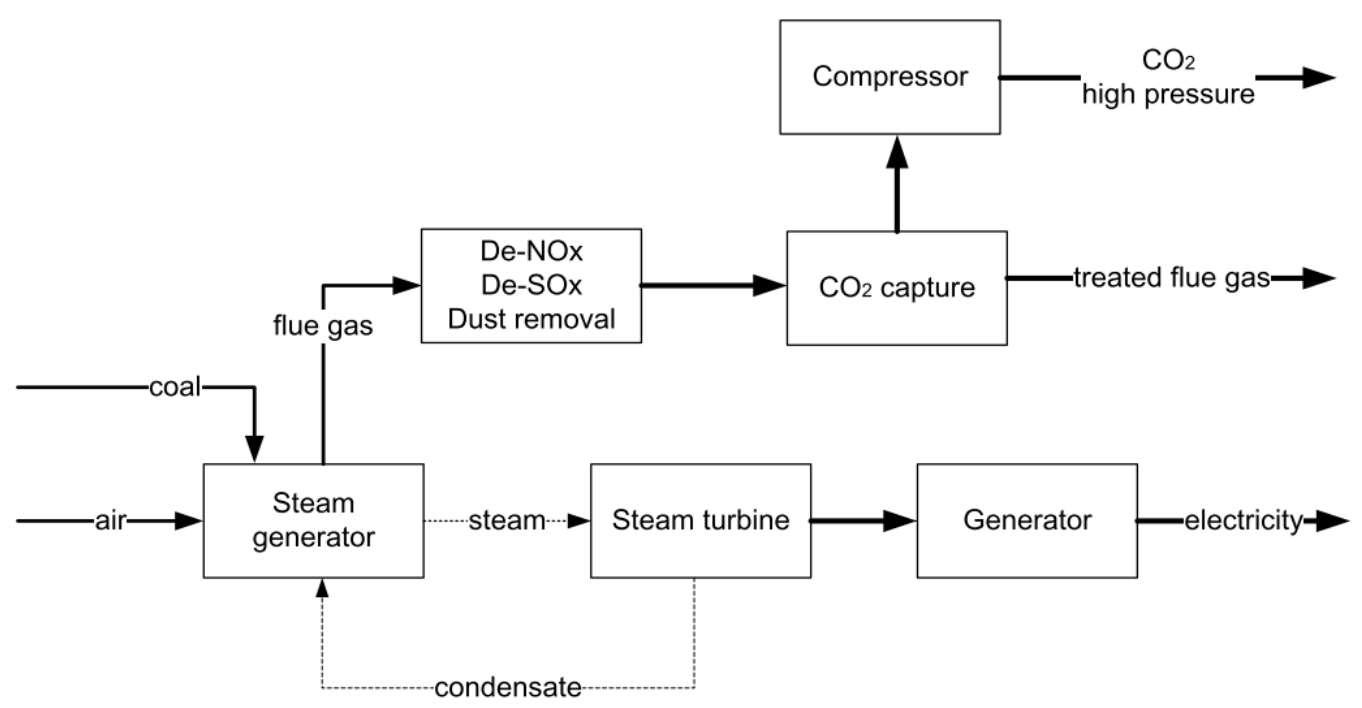

Gambar 4. Diagram Skematik PLTU Batubara dengan Penangkapan $\mathrm{CO}_{2}$ Paska-Pembakaran

(Wang et al., 2017)

\subsubsection{Absorbsi Kimia}

Saat ini, metode penyerapan kimia yang paling matang didasarkan pada larutan berdasi etanolamin, seperti mono-ethanolamine (MEA), two-ethanolamine, dan methyl-two-ethanolamine (Ye et al., 2019). Dalam proses absorbsi kimia flue gas memasuki absorber dari bagian bawah dan mengalir ke atas sementara larutan kimia pelarut turun ke bawah, membentuk aliran yang berlawanan arah. Melalui kontak kedua aliran ini, bagian dari $\mathrm{CO}_{2}$ dalam flue gas diserap ke dalam larutan kimia, umumnya amine. Kemudian larutan dengan $\mathrm{CO}_{2}$ yang telah diserap, biasa disebut larutan richloading, dipompa ke stripper. Dalam stripper, juga terdapat aliran berlawanan arah dengan larutan richloading yang mengalir ke bawah kolom dan uap stripper yang dihasilkan oleh reboiler mengalir ke atas. Panas dari uap stripper melepaskan ikatan kimia antara $\mathrm{CO}_{2}$ dan pelarut sehingga $\mathrm{CO}_{2}$ dibawa oleh uap naik ke arah kondenser. Sementara kondensat diarahkan kembali ke stripper sebagai refluks, aliran produk dengan kemurnian $\mathrm{CO}_{2}$ tinggi (sekitar 99\%) diperoleh. Kemudian aliran produk dapat dikompresi untuk transportasi ke tempat penyimpanan. Di bagian bawah stripper, larutan amine yang disebut sebagai larutan lean-loading dipompa kembali ke absorber. Sebelum memasuki absorber, larutan lean-loading dengan suhu yang relatif tinggi digunakan untuk meningkatkan suhu larutan rich-loading.

MEA tidak hanya bereaksi dengan $\mathrm{CO}_{2}$ tetapi juga dapat bereaksi dengan gas asam, seperti $\mathrm{SOx}, \mathrm{HCl}$, dan $\mathrm{NxO}$. Oleh karena itu, gas-gas ini akan sangat meningkatkan konsumsi MEA adsorbent yang mahal. Karena konsentrasi SOx dalam flue gas jauh lebih tinggi daripada yang ada di gas asam lainnya maka desulfurisasi flue gas sebelum menjadi sangat penting (Ye et al., 2019).

Saat ini kendala utama dari teknologi ini adalah kebutuhan energi yang sangat tinggi terutama pada proses regenerasi Amine (Elias et al., 2018). Roeder dkk membuat model PLTU batubara 600 MW dan simulasi absorbsi kimia dengan MEA (Roeder \& Kather, 2014). Hasilnya menunjukan bahwa efisiensi pembangkit turun $10.7 \%$ pada beban $100 \%$. Pemodelan pada artikel lain (Cifre et al., 2009) menunjukan bahwa penerapan proses absorbsi kimia pada PLTU Batubara 600 MW dan 1000 MW akan menurunkan efisiensi sebesar 14\% dan 16\%. 


\subsubsection{Absorbsi Membran}

Sebelum memasuki modul membran, scrubber basah sering digunakan untuk mendinginkan flue gas ke suhu operasional membran. Di dalam modul membran, sebagian $\mathrm{CO}_{2}$ meresap melalui membran dan aliran (gas permeate) dengan konsentrasi $\mathrm{CO}_{2}$ yang lebih tinggi diperoleh di sisi permeate. Bagian yang tersisa dari flue gas disebut gas retentate. Tekanan parsial $\mathrm{CO}_{2}$ pada flue gas sangat kecil sehingga kompresor dan pompa vakum digunakan untuk meningkatkan perbedaan tekanan parsial antara inlet dan sisi permeate. Dibandingkan dengan proses penyerapan bahan kimia, proses pemisahan membran rupanya lebih sederhana dan mengandung lebih sedikit komponen. Konsumsi energi utama berasal dari kompresor dan pompa vakum.

Material membran yang bisa digunakan adalah membran keramik (inorganik), membran polimerik (organik), dan membran hibrid (Low et al., 2013). Keunggulan dan kerugian dari ketiganya telah dibahas (Ramasubramanian \& Ho, 2011). Membran polimerik biasanya dioperasikan di bawah suhu rendah dan memiliki stabilitas termal serta kekuatan mekanis yang lebih baik dibandingkan dengan membran keramik. Selain itu, membran polimer lebih mudah diproduksi dengan area yang luas. Membran keramik termasuk silika dan membran zeolite memberikan trade-off selektivitas permeabilitas yang lebih baik. Seletivitas dan permeability adalah properti utama bahan membran untuk pemisahan gas. Namun, membuat lapisan bebas cacat dan produk dengan luas permukaan yang besar jauh lebih sulit daripada membran polimer. Aliran flue gas biasanya sangat besar sehingga diperlukan permukaan membran yang cukup luas.

\subsubsection{Adsorpsi}

Proses adsorpsi adalah peristiwa tertariknya suatu molekul tertentu dari fluida (cair atau gas) pada permukaan zat padat (adsorben). Tidak seperti proses absorpsi, pembentukan ikatan fisik atau kimia terjadi antara permukaan adsorbent fase padat dan $\mathrm{CO}_{2}$. Kekuatan intermolekuler antara permukaan padat dan gas adalah kekuatan pendorong untuk adsorpsi. Pemisahan $\mathrm{CO}_{2}$ menggunakan proses adsorpsi memerlukan kolom diisi dengan adsorbent. Kemudian, aliran flue gas pembawa $\mathrm{CO}_{2}$ dialirkan melalui kolom ini. $\mathrm{CO}_{2}$ melekat pada permukaan padat adsorben sampai adsorben jenuh. Ketika permukaan adsorben jenuh, $\mathrm{CO}_{2}$ dilepaskan melalui beberapa jenis siklus regenerasi.

Umumnya, empat jenis siklus regenerasi digunakan untuk adsorpsi $\mathrm{CO}_{2}$. Siklus-siklus tersebut adalah pressure swing adsorption (PSA), temperature swing adsorption (TSA), electrical swing adsorption (ESA), dan vacuum swing adsorption (VSA). Dalam TSA, suhu adsorbent dinaikkan hingga titik di mana ikatan kimia lepas. $\mathrm{CO}_{2}$ akan terlepas pada saat itu. Kebutuhan energi dalam proses ini membuat metode ini lebih mahal. Proses ini juga memakan waktu untuk memanaskan adsorben untuk desorpsi dan mendinginkannya lagi untuk untuk adsorpsi. Proses ini dapat dilakukan dengan cepat menggunakan ESA. Di sini, arus listrik tegangan rendah diteruskan melalui adsorbent untuk memanaskan adsorbent menggunakan efek joule. ESA memungkinkan untuk meregenerasi adsorbent dengan cepat, tetapi membutuhkan energi listrik yang berkualitas. Pada PSA, proses regenerasi dilakukan dengan cara menurunkan tekanan absorbedn. Vacuum swing adsorption adalah siklus PSA khusus yang digunakan jika tekanan flue gas dekat dengan tekanan ambien.

Metode adsorpsi diyakini sebagai salah satu potensi penangkapan karbon pasca-pembakaran paling ekonomis karena memerlukan energi lebih kecil dan sedikit modifikasi yang diperlukan pada pembangkit listrik yang ada. Namun material yang ada saat ini memiliki selektivitas yang rendah terhadap $\mathrm{CO}_{2}$ dalam flue gas (Ben-Mansour et al., 2016). Material baru diharapak memiliki selektivitas 
Vol. 2, No. 1, pp $27-35$

doi: $10.14710 /$ jebt.2021.10046

tinggi dan adsorpsi tinggi stabilitas tinggi $\mathrm{CO}_{2}$ dengan uap air, stabilitas termal yang baik, konduktivitas termal yang baik, panas spesifik tinggi, ketahanan korosi yang baik serta kekuatan mekanik yang cukup untuk menahan siklus berulang.

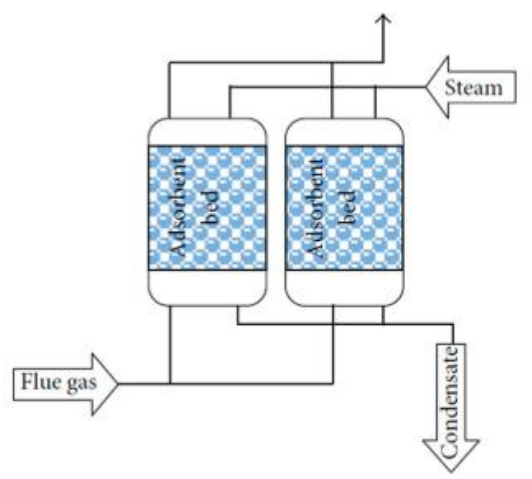

(a)

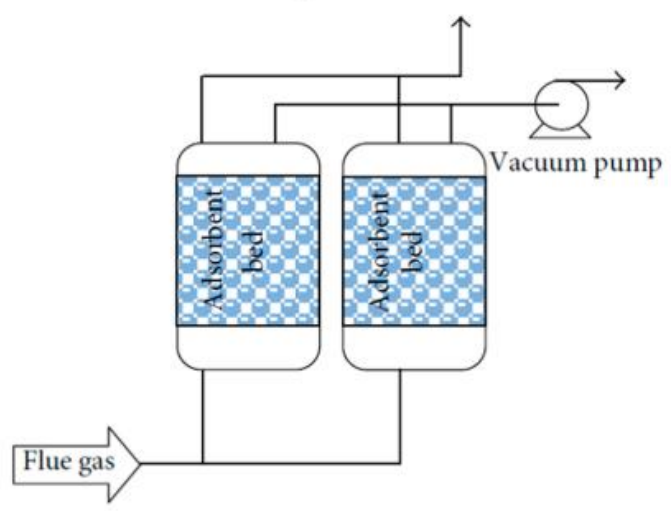

(c)

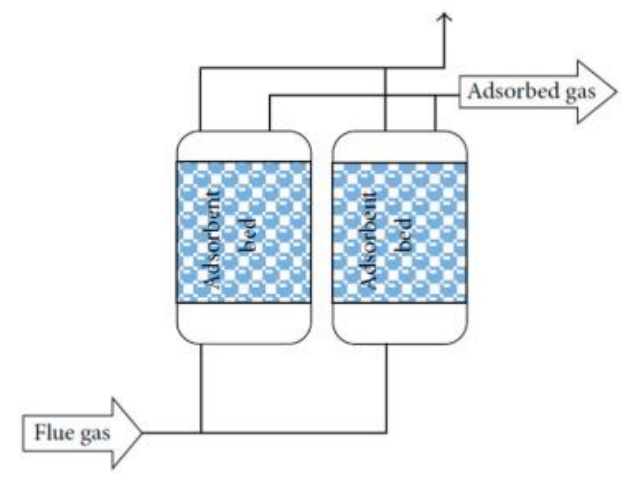

(b)

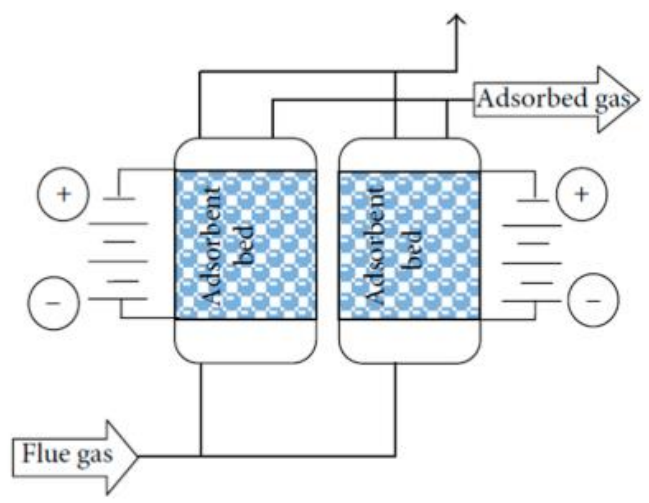

(d)

Gambar 5. Diagram skematik siklus regenerasi adsorpsi; (Sifat \& Haseli, 2019).
a) TSA
b) PSA
c) VSA

\subsubsection{Pemisahan kriogenik}

Metode cryogenic menggunakan suhu rendah untuk kondensasi, pemisahan, dan pemurnian $\mathrm{CO}_{2}$ dari flue gas (titik beku $\mathrm{CO}_{2}$ adalah $195,5 \mathrm{~K}$ pada tekanan atmosfer). Dengan demikian $\mathrm{CO}_{2}$ dapat dipisahkan oleh serangkaian langkah kompresi, pendinginan, dan ekspansi. Proses ini memungkinkan produksi langsung $\mathrm{CO}_{2}$ cair yang dapat disimpan atau disimpan pada tekanan tinggi.

Keuntungan utama dari proses penangkapan $\mathrm{CO}_{2}$ kriogenik adalah kemurnian produk yang tinggi. Proses penangkapan $\mathrm{CO}_{2}$ Cryogenic juga dianggap sebagai teknologi hijau karena penangkapan $\mathrm{CO}_{2}$ berlangsung tanpa pelarut organik (Babar et al., 2019). $\mathrm{CO}_{2}$ cair juga diproduksi secara langsung, sehingga membuatnya relatif mudah untuk disimpan atau dikirim untuk pemulihan minyak yang ditingkatkan (Zanganeh et al., 2009). Kerugian utama dari proses ini adalah banyaknya energi yang diperlukan untuk menyediakan pendinginan dan solidifikasi $\mathrm{CO}_{2}$ di bawah suhu rendah, yang menyebabkan beberapa masalah operasional (Lively et al., 2012) 


\section{Kesimpulan}

Sambil menunggu teknologi energi terbarukan cukup matang dan mengganti bahan bakar berbasis fosil, penerapan teknologi penangkapan karbon sangat penting. Banyak studi pemodelan eksperimental dan numerik telah dilakukan pada proses penangkapan karbon. Di sini, kami meninjau tiga rute utama penangkapan karbon: pra-pembakaran, pasca-pembakaran dan rute pembakaran oksifuel

Penangkapan pembakaran oksifuel adalah metode yang menjanjikan. Ruang bakar yang lebih kecil, pengurangan emisi SOx dan Nox, dan yang terutama konsentrasi $\mathrm{CO}_{2}$ yang tinggi pada flue gas. Tetapi metode ini memiliki beberapa masalah yaitu biaya dan energi yang dibutuhkan memproduksi oksigen murni sangat mahal. Pembakaran oxigen murni juga menyebabkan temperatur yang sangat tinggi.

Pada penangkapan $\mathrm{CO}_{2}$ pra-pembakaran, jumlah $\mathrm{CO}_{2}$ dalam flue gas jauh lebih tinggi dibanding dalam flue gas pembangkit konvensional. Karena tekanan yang lebih tinggi dan volume gas yang lebih rendah, lebih sedikit energi diperlukan dalam proses ini dibandingkan dengan penangkapan pasca-pembakaran. Pra-pembakaran kebanyakan digunakan dalam teknologi yang terintregasi dengan gasifikasi. Teknologi ini menuntut sistem tambahan yang besar untuk kelancaran operasi. Oleh karena itu, biaya modal sistem ini terlalu tinggi dibandingkan dengan sistem lain.

Pada pembangkit konvensional, tekanan parsial dan konsentrasi $\mathrm{CO}_{2}$ dalam flue gas sangat rendah. Hal ini menjadi tantangan utama metode penangkapan $\mathrm{CO}_{2}$ paska-pembakaran Persyaratan produk akhir $\mathrm{CO}_{2}$ untuk transportasi sangat ketat (kemurnian $\mathrm{CO}_{2}>95 \%$, tekanan $=110$ bar). Untuk mencapai persyaratan ini dibutuhkan energi dan biaya yang tinggi. Metode ini juga membutuhkan flue gas yang bebas sulfur. Keuntungan utama dari penangkapan paska pembakaran adalah integrasi mudah dengan pembangkit listrik yang ada. Karena hal ini sebagian besar kajian diarahkan pada metode paska-pembakaran.

Penambahan kapasitas pembangkit batubara di Indonesia tidak diimbangi oleh kenaikan konsumsi listrik yang sesuai rencana PLN. Pandemi dan resesi yang dialami Indonesia akan memperbesar gap ini. Pemerintah telah memutuskan untuk tidak membangun pembangkit batubara di Jawa. Kondisi-kondisi ini membuat metode penangkapan $\mathrm{CO}_{2}$ yang cocok diterapkan di Indonesia adalah paska-pembakaran dengan mengintegrasikannya pada pembangkit yang sudah ada. Tentu saja dibutuhkan dukungan pemerintah untuk mengkompensasi kenaikan biaya operasi dan turunnya efisiensi pembangkit. Ini bisa dimulai dengan menerapkan kebijakan insentif untuk penurunan emisi karbon atau mengenakan pajak emisi karbon.

\section{Daftar Pustaka}

Babar, M., Bustam, M. A., Ali, A., Shah Maulud, A., Shafiq, U., Mukhtar, A., Shah, S. N., Maqsood, K., Mellon, N., \& Shariff, A. M. (2019). Thermodynamic data for cryogenic carbon dioxide capture from natural gas: A review. Cryogenics, 102(March), 85-104. https://doi.org/10.1016/j.cryogenics.2019.07.004

Ben-Mansour, R., Habib, M. A., Bamidele, O. E., Basha, M., Qasem, N. A. A., Peedikakkal, A., Laoui, T., \& Ali, M. (2016). Carbon capture by physical adsorption: Materials, experimental investigations and numerical modeling and simulations - A review. Applied Energy, 161, 225-255. https://doi.org/10.1016/j.apenergy.2015.10.011 
Cifre, P. G., Brechtel, K., Hoch, S., García, H., Asprion, N., Hasse, H., \& Scheffknecht, G. (2009). Integration of a chemical process model in a power plant modelling tool for the simulation of an amine based CO2 scrubber. Fuel, 88(12), 2481-2488. https://doi.org/10.1016/j.fuel.2009.01.031

Edge, P., Gharebaghi, M., Irons, R., Porter, R., Porter, R. T. J., Pourkashanian, M., Smith, D., Stephenson, P., \& Williams, A. (2011). Combustion modelling opportunities and challenges for oxycoal carbon capture technology. Chemical Engineering Research and Design, 89(9), 1470-1493. https://doi.org/10.1016/j.cherd.2010.11.010

Elias, R. S., Wahab, M. I. M., \& Fang, L. (2018). Retrofitting carbon capture and storage to natural gas-fired power plants: A real-options approach. Journal of Cleaner Production, 192, 722-734. https://doi.org/10.1016/j.jclepro.2018.05.019

Figueroa, J. D., Fout, T., Plasynski, S., Mcllvried, H., \& Srivastava, R. D. (2008). Advances in $\mathrm{CO} 2$ capture technology-The U.S. Department of Energy's Carbon Sequestration Program. International Journal of Greenhouse Gas Control, 2(1), 9-20. https://doi.org/10.1016/S17505836(07)00094-1

Jansen, D., Gazzani, M., Manzolini, G., Dijk, E. Van, \& Carbo, M. (2015). Pre-combustion CO2 capture. International Journal of Greenhouse Gas Control, 40, 167-187. https://doi.org/10.1016/j.ijggc.2015.05.028

Lively, R. P., Koros, W. J., \& Johnson, J. R. (2012). Enhanced cryogenic CO 2 capture using dynamically operated low-cost fiber beds. Chemical Engineering Science, 71, 97-103. https://doi.org/10.1016/j.ces.2011.11.042

Lockwood, T. (2017). A Compararitive Review of Next-generation Carbon Capture Technologies for Coal-fired Power Plant. Energy Procedia, 114(November 2016), 2658-2670. https://doi.org/10.1016/j.egypro.2017.03.1850

Low, B. T., Zhao, L., Merkel, T. C., Weber, M., \& Stolten, D. (2013). A parametric study of the impact of membrane materials and process operating conditions on carbon capture from humidified flue gas. Journal of Membrane Science, 431, 139-155. https://doi.org/10.1016/j.memsci.2012.12.014

Merkel, T. C., Lin, H., Wei, X., \& Baker, R. (2010). Power plant post-combustion carbon dioxide capture: An opportunity for membranes. Journal of Membrane Science, 359(1-2), 126-139. https://doi.org/10.1016/j.memsci.2009.10.041

Ramasubramanian, K., \& Ho, W. S. W. (2011). Recent developments on membranes for postcombustion carbon capture. Current Opinion in Chemical Engineering, 1(1), 47-54. https://doi.org/10.1016/j.coche.2011.08.002

Roeder, V., \& Kather, A. (2014). Part load behaviour of power plants with a retrofitted postcombustion CO2 capture process. Energy Procedia, 51, 207-216. https://doi.org/10.1016/j.egypro.2014.07.024

RUPTL PT. PLN. (2019). Rencana usaha penyediaan tenaga listrik pt. pln (persero) 2019 - 2028. 2019-2028.

Sifat, N. S., \& Haseli, Y. (2019). A critical review of CO2 capture technologies and prospects for clean power generation. Energies, 12(21). https://doi.org/10.3390/en12214143

Stanger, R., Wall, T., Spörl, R., Paneru, M., Grathwohl, S., Weidmann, M., Scheffknecht, G., McDonald, D., Myöhänen, K., Ritvanen, J., Rahiala, S., Hyppänen, T., Mletzko, J., Kather, A., \& Santos, S. (2015). Oxyfuel combustion for $\mathrm{CO} 2$ capture in power plants. International Journal of Greenhouse Gas Control, 40, 55-125. https://doi.org/10.1016/j.ijggc.2015.06.010 
Thiruvenkatachari, R., Su, S., An, H., \& Yu, X. X. (2009). Post combustion CO2 capture by carbon fibre monolithic adsorbents. Progress in Energy and Combustion Science, 35(5), 438-455. https://doi.org/10.1016/j.pecs.2009.05.003

Wang, Y., Zhao, L., Otto, A., Robinius, M., \& Stolten, D. (2017). A Review of Post-combustion CO2 Capture Technologies from Coal-fired Power Plants. Energy Procedia, 114(November 2016), 650665. https://doi.org/10.1016/j.egypro.2017.03.1209

Ye, B., Jiang, J., Zhou, Y., Liu, J., \& Wang, K. (2019). Technical and economic analysis of aminebased carbon capture and sequestration at coal-fired power plants. Journal of Cleaner Production, 222, 476-487. https://doi.org/10.1016/j.jclepro.2019.03.050

Yuan, P., Qiu, Z., \& Liu, J. (2017). Recent enlightening strategies for co2 capture: A review. IOP Conference Series: Earth and Environmental Science, 64(1). https://doi.org/10.1088/1755$1315 / 64 / 1 / 012046$

Zanganeh, K. E., Shafeen, A., \& Salvador, C. (2009). CO2 Capture and Development of an Advanced Pilot-Scale Cryogenic Separation and Compression Unit. Energy Procedia, 1(1), 247-252. https://doi.org/10.1016/j.egypro.2009.01.035 